\title{
Synthesis and Crystal Structure of a Dimethyltin Derivative of 1,4-Dithioerythritol
}

\author{
ChunLin MA, ${ }^{* \dagger}$ Zhifo Guo, $* *$ and Rufen ZHANG** \\ *Department of Materials Science and Chemical Engineering, Chemistry, Taishan University, \\ Taian, 271021, P. R. China \\ **Department of Chemistry Liaocheng University, Liaocheng 252059, P. R. China.
}

\begin{abstract}
The title complex, $\left[\left(\mathrm{CH}_{3}\right)_{2}\left(\mathrm{HOC}_{2} \mathrm{H}_{5}\right) \mathrm{Sn}\left(\mathrm{C}_{4} \mathrm{H}_{6} \mathrm{O}_{2} \mathrm{~S}_{2}\right) \mathrm{Sn}\left(\mathrm{HOC}_{2} \mathrm{H}_{5}\right)\left(\mathrm{CH}_{3}\right)_{2}\right]$, was synthesized starting from dimethyltin dichloride, 1,4-dithioerythritol and sodium ethoxide. The crystal structure was determined by single-crystal X-ray diffraction. It crystallizes in the monoclinic system, space group $P 2_{1} / n$ with $a=7.9282(6) \AA, b=11.3888(9) \AA, c=$ 11.0228(9) $\AA, \beta=99.594(3)^{\circ}, Z=2, V=981.36(13) \AA^{3}$. Its crystal structure was determined and refined to a final $R=$ 0.0232 for 1730 independent reflections. The complex is the symmetric dinuclear unit made up of two distorted trigonal bipyramids.
\end{abstract}

(Received November 15, 2007; Accepted January 15, 2008; Published on wed February 26, 2008)

Since some organotin(IV) compounds have been found to exhibit antitumour activity in vitro, many varieties of organotin(IV) compounds have been synthesized and studied in the context of their antitumour potential. ${ }^{1}$ However, 1,4dithioerythritol is also a protective agent for preventing oxidation of thiol groups and a reagent for the reduction of disulfide groups in proteins. ${ }^{2-4}$ Our interest has been focused on studying the reaction under a mild condition and hoping to obtain a novel organotin complex with potential biological activities. In this paper, we report on the synthesis and crystal structure of a dimethyltin derivative of 1,4-dithioerythritol.

Dimethyltin dichloride and 1,4-dithioerythritol are commercially available, which were used without further

Table 1 Crystal and experimental data

\begin{tabular}{ll} 
Formula & $\mathrm{C}_{11} \mathrm{H}_{30} \mathrm{O}_{4} \mathrm{~S}_{2} \mathrm{Sn}_{2}$ \\
Formula weight & 527.85 \\
Crystal system & monoclinic \\
Space group & $P 2_{1} / n$ \\
$a$ & $7.9282(6) \AA$ \\
$b$ & $7.9282(6) \AA$ \\
$c$ & $11.0228(9) \AA$ \\
$\beta$ & $99.594(3)^{\circ}$ \\
$V$ & $981.36(13) \AA^{3}$ \\
$D_{\mathrm{X}}$ & $1.786 \mathrm{Mg} / \mathrm{m}^{3}$ \\
$F(000)$ & 520 \\
$\theta$ range for data collection & 2.59 to $25.01^{\circ}$ \\
Reflections used & $1730[R(\mathrm{int})=0.0321]$ \\
& $R 1=0.0232, w R 2=0.0630$ \\
Measurement & $\mathrm{BRUKER} \mathrm{SMART} 1000 \mathrm{CCD}$ \\
Mo $K_{\alpha}$ & $\lambda=0.71073 \AA$ \\
Structure determination & direct method \\
Refinement & Full-matrix \\
CCDC & 655986 \\
\hline
\end{tabular}

$\dagger$ To whom correspondence should be addressed. E-mail:macl@1cu.edu.cn purification. Complex $\mathbf{1}$ was prepared under a nitrogen atmosphere using a standard Schlenk technique. The 1,4dithioerythritol $(0.154 \mathrm{~g}, 1 \mathrm{mmol})$ was added to a solution of ethanol $(20 \mathrm{~mL})$ with sodium ethoxide $(0.136 \mathrm{~g}, 2 \mathrm{mmol})$; the mixture was stirred for $10 \mathrm{~min}$, after which $\mathrm{Me}_{2} \mathrm{SnCl}_{2}(0.439 \mathrm{~g}$, $2 \mathrm{mmol}$ ) was added, and the mixture was stirred for $12 \mathrm{~h}$ at $40^{\circ} \mathrm{C}$. After cooling down to the room temperature, the solution was filtered. The solvent of the filtrate was gradually removed by evaporation under a vacuum until a solid product was obtained. The solid was then recrystallized from ether-petroleum, and yellow crystals were formed in $70 \%$ yield.

A weak yellow crystal of dimentions $0.35 \times 0.33 \times 0.30 \mathrm{~mm}$ was chosen for X-ray diffraction studies. The experimental conditions, crystal data and structure refinement results of complex $\mathbf{1}$ are summarized in Table 1; the atomic coordinates and temperature factors are listed in Table 2, and selected bond lengths and angles are listed in Table 3.

The chemical diagram and crystal structure of the title complex is shown in Figs. 1 and 2, respectively.

The complex is a symmetric dinuclear unit made up of two distorted coordination trigonal bipyramids. The five primary bonds to $\mathrm{Sn}$ are two methyl groups, one ethanol molecule, and

Table 2 Atomic coordinates $\left(\times 10^{4}\right)$ and temperature factors $\left(\AA^{2} \times 10^{3}\right)$ for title the complex

\begin{tabular}{lllll}
\hline Atom & \multicolumn{1}{c}{$x$} & $y$ & \multicolumn{1}{c}{$z$} & $U_{(\mathrm{eq})}$ \\
\hline $\mathrm{Sn}(1)$ & $2598(1)$ & $1583(1)$ & $1942(1)$ & $40(1)$ \\
$\mathrm{S}(1)$ & $3067(2)$ & $1470(1)$ & $-146(1)$ & $48(1)$ \\
$\mathrm{O}(1)$ & $1245(3)$ & $10(2)$ & $1566(2)$ & $41(1)$ \\
$\mathrm{O}(2)$ & $4107(5)$ & $3367(3)$ & $1900(4)$ & $55(1)$ \\
$\mathrm{C}(1)$ & $2318(5)$ & $-43(4)$ & $-365(4)$ & $48(1)$ \\
$\mathrm{C}(2)$ & $817(5)$ & $-303(3)$ & $304(4)$ & $40(1)$ \\
$\mathrm{C}(3)$ & $540(7)$ & $2612(5)$ & $2351(6)$ & $73(2)$ \\
$\mathrm{C}(4)$ & $4504(8)$ & $959(5)$ & $3376(5)$ & $83(2)$ \\
$\mathrm{C}(5)$ & $5772(8)$ & $3427(5)$ & $1594(6)$ & $73(2)$ \\
$\mathrm{C}(6)$ & $6098(18)$ & $4201(10)$ & $882(12)$ & $123(4)$ \\
\hline
\end{tabular}


Table 3 Selected bond lengths $(\AA)$ and angles $\left({ }^{\circ}\right)$

\begin{tabular}{llll}
\hline $\mathrm{Sn}(1)-\mathrm{O}(1)$ & $2.093(3)$ & $\mathrm{Sn}(1)-\mathrm{O}(2)$ & $2.363(3)$ \\
$\mathrm{Sn}(1)-\mathrm{C}(3)$ & $2.118(5)$ & $\mathrm{Sn}(1)-\mathrm{S}(1)$ & $2.3950(12)$ \\
$\mathrm{Sn}(1)-\mathrm{C}(4)$ & $2.119(5)$ & & \\
$\mathrm{O}(1)-\mathrm{Sn}(1)-\mathrm{C}(3)$ & $97.38(17)$ & $\mathrm{C}(4)-\mathrm{Sn}(1)-\mathrm{O}(2)$ & $90.12(18)$ \\
$\mathrm{O}(1)-\mathrm{Sn}(1)-\mathrm{C}(4)$ & $97.99(17)$ & $\mathrm{O}(1)-\mathrm{Sn}(1)-\mathrm{S}(1)$ & $85.45(8)$ \\
$\mathrm{C}(3)-\mathrm{Sn}(1)-\mathrm{C}(4)$ & $120.4(3)$ & $\mathrm{C}(3)-\mathrm{Sn}(1)-\mathrm{S}(1)$ & $118.88(18)$ \\
$\mathrm{O}(1)-\mathrm{Sn}(1)-\mathrm{O}(2)$ & $167.59(12)$ & $\mathrm{C}(4)-\mathrm{Sn}(1)-\mathrm{S}(1)$ & $119.5(2)$ \\
$\mathrm{C}(3)-\mathrm{Sn}(1)-\mathrm{O}(2)$ & $86.47(17)$ & $O(2)-\operatorname{Sn}(1)-\mathrm{S}(1)$ & $82.37(10)$ \\
\hline
\end{tabular}

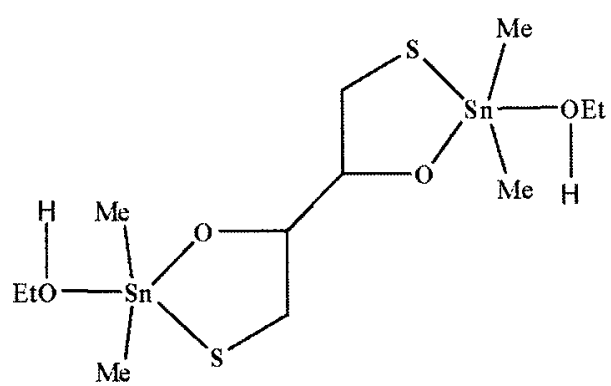

Fig. 1 Structural chemical diagram.

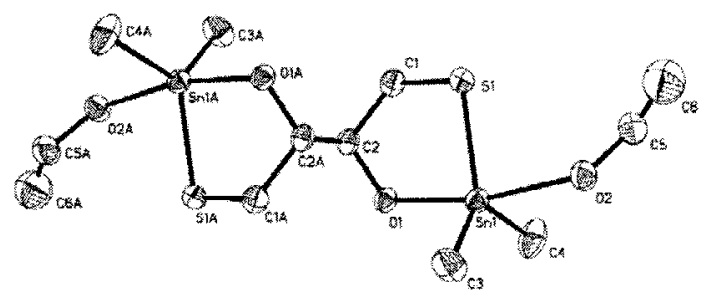

Fig. 2 Molecular structure.

one oxygen atom and one sulfur atom. The coordination mode, bond lengths and bond angles of the two $\mathrm{Sn}$ atoms are completely same. Taking $(\operatorname{Sn}(1))$ for example, the trigonal equatorial plane is occupied by the sulfur $\mathrm{S}(1)$ atom and two carbon atoms, C(3) and C(4), whereas the axial positions were located by two oxygen atoms with an axial-Sn-axial angle of $\mathrm{O}(1)-\mathrm{Sn}(1)-\mathrm{O}(2) 167.59^{\circ}$. The sum of the equatorial angles around the $\mathrm{Sn}(1)$ atom $(\mathrm{C}(3)-\mathrm{Sn}(1)-\mathrm{S}(1), \mathrm{C}(4)-\mathrm{Sn}(1)-\mathrm{S}(1)$ and $\mathrm{C}(3)-\mathrm{Sn}(1)-\mathrm{C}(4))$ is $358.78^{\circ}$. In this way the ligand behaves as a

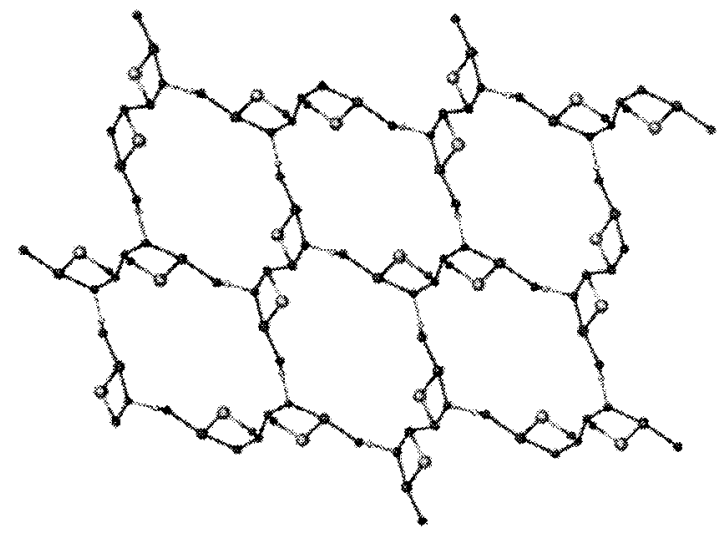

Fig. 3 Two-dimensional network connected by $\mathrm{O}-\mathrm{H} \cdots \mathrm{O}$ hydrogen bonds, hydrogen atoms, carbon atoms of the ethanol group; the Snmethyl groups have been omitted for clarity.

bidentate species and chelates the tin atom by means of the oxygen and the sulfur. The consequence is the formation of a five-member ring with an $\mathrm{S}-\mathrm{Sn}-\mathrm{O}$ bite angle of $82.37(10)^{\circ}$.

The bond lengths around $\mathrm{Sn}(1)$ are close to those found in $\left[\mathrm{Me}_{2} \mathrm{Sn}\left(o-\mathrm{SC}_{6} \mathrm{H}_{4} \mathrm{CO}_{2}\right)\right]_{6}\left(\mathrm{H}_{2} \mathrm{O}\right){ }^{5}$ What is more, the discrete molecules are connected through an $\mathrm{O}-\mathrm{H} \cdots \mathrm{O}$ hydrogen bond into a two-dimensional network (see Fig. 3).

\section{Acknowledgements}

The authors thank the National Natural Science Foundation of China (20271025) for financial support.

\section{References}

1. M. Gielen, Appl. Organomet. Chem., 2002, 16, 481.

2. W. L. Zahler and W. W. Cleland, J. Biol. Chem., 1968, 243, 716 .

3. Y. Burstein and A. Patchornik, Biochemistry, 1972, 11, 2939.

4. W. W. Cleland, Biochemistry, 1963, 3, 480.

5. C. L. Ma, Q. F. Zhang, R. F. Zhang, and D. Q. Wang, Chem. Eur. J., 2006, 12, 420. 